\title{
HSP90B2P Gene
}

National Cancer Institute

\section{Source}

National Cancer Institute. HSP90B2P Gene. NCI Thesaurus. Code C116982.

This gene may play a role in protein folding. 